\title{
The Influence of Monitor Comprehension towards Students' Reading Comprehension Achievement
}

\author{
Elya Anggraini ${ }^{1}$, Warno Edi ${ }^{2}$, Yuli Angraini ${ }^{3}$ \\ English Education Department \\ University of Riau Kepulauan \\ elyaanggraini223@gmail.com ${ }^{1}$,warnopyaar@yahoo.com ${ }^{2}$,angraini_yuli@yahoo.com ${ }^{3}$
}

\begin{abstract}
This research was about Monitor Comprehension Strategy (MCS) to the reading comprehension of students in class 8 SMPN 9 Batam in academic year 2015/2016. The purpose of this study was to find the influence of strategy on reading comprehension of students. To get the purpose of the study, researchers conducted research experiments. 5QAAnumber of students is 210. Researchers used a purposive sampling technique to determine the grade of research. The subject was VIII.4 and VIII.7 classes totaling 30 students each class. Researchers conduct research in two classes. The first class (VIII.4) as experimental class and the second class (VIII.7) as the control class. In analyzing the data researchers used quantitative calculation to find the result. Data were analyzed showed significant differences before getting treatment for an average of 67.50 and 67.17 for the control class. The average score obtained student after getting treatment in the experimental class are 82.50 and 78.50. Based on these result, the use of Monitor comprehension strategy gives significant influence on student's reading comprehension.
\end{abstract}

Keywords: students’ reading comprehension, monitor comprehension strategy.

\section{INTRODUCTION}

English is a foreign language. It is taught formally from elementary school up to university level. It is used as one of the subject in national examination. In teaching learning process, there are language skills to be learned by the students such as reading, listening, writing and speaking. Reading is one of the most important academic skills in learning English. By reading, students will get maximum information than lesson that is given by teacher which has limited time. It is very important for student to learn reading because students who can read well would be able to increase their knowledge through reading and get information by themselves.

Some problems that faced by students in learning English, especially in reading comprehension there are, the students still have difficulties in understanding reading texts and 
the students feel bored in reading the reading text. The teachers do not use various techniques so students get difficulties in learning English especially in reading comprehension and make students feel bored on it. They only use traditional teaching because of many problems that faced by the students in reading. The writer needs to limit this problem. This research will be limited into teaching "reading comprehension by applying Monitor Comprehension Strategy (MCS) in descriptive text.” This strategy will be applied at grade eight of SMPN 9 Batam in academic year 2015/2016.

The objective of the study is to know whether there is significant effect in Monitor Comprehension Strategy towards students reading comprehension achievement. Significance of the study, the study is use to for student to encourage the students' motivation in learning English especially in improve their reading comprehension and Give the students' an interesting technique of presenting the material in older to improve their ability to comprehend and master reading. And then for English teacher can use this Monitor Comprehension Strategy in the class, so the students can be more active and interest in learning and MCS can help the English Teacher to teach English in various strategy and for improving students’ interest in reading.

\section{METHODOLOGY}

Research can be divided into two broad categories: quantitative research and qualitative research. In this research, the researcher uses a quantitative with experimental design. Quantitative research consists of research in which the data can be analyzed in terms of number.

According to Best John (2006: 177), experimental design is the blueprint of the procedures that enable the researcher to test hypothesis by reaching valid conclusion about relationship between independent and dependent variables.

In experimental research, The writer divided into two sample groups. They are an experimental and control group. The experimental group classified to Monitor Comprehension Strategy. Therefore, the experimental group would give pre- test, MCS strategy and post- test. While the control group gave pre- test, DRTA strategy and post - test.

In this research, the population was the second grade students of Junior High School or SMP N 9 Batam. The total number of the population is 210 students. They were distribute into seven classes, each class consist of 30 students. The sample of this study consists of two 
class, in this research, one class for experimental class and the other for control class. The sample in this research are class VIII.4 for experiment class and class VIII.7 for control class.

In this research, the technique of selecting sample was purposive sampling technique. Purposive sampling is sampling technique for a particular purpose. Purposive sampling could also mean sampling to determine the target specific groups, Arikunto (2006:139).

In order to be able to measure the students' reading comprehension in learning English. It came from the evaluation conducted or test. The test consists of 40 items in multiple choices, and the sources of the test was from the book of Junior High School based on the school curriculum. The test was use for pre-test and post-test.

\section{Population, Sample and Sampling Technique}

\section{Population}

The writer takes the population to do the experiment and the population of this research at $8^{\text {th }}$ grade students of SMPN 9 Batam, which is consist of 210 students.

Table 1. Population of the students

\begin{tabular}{cc}
\hline Class & \multicolumn{1}{c}{ Total } \\
\hline VIII. 1 & 30 Students \\
\hline VIII. 2 & 30 Students \\
\hline VIII. 3 & 30 Students \\
\hline VIII. 4 & 30 Students \\
\hline VIII. 5 & 30 Students \\
\hline VIII. 6 & 30 Students \\
\hline VIII. 7 & 30 Students \\
\hline Total & 210 Students
\end{tabular}

\section{Sample}

In this research as quasi experiment research, there are two sample, experimental class and control class. Experiment class is VIII. 4 and control class is VIII. 7.

\section{Sampling Technique}

Sampling Technique is a mean that is used by the writer to take the sample of research (Sugiyono, 2009:81). Arikunto (2006:139) said that purposive sampling is a sampling technique for a particular purpose. Purposive sampling could also mean sampling to 
determine the target specific groups. In this research the researcher used purposive sampling because when the researcher want to do the research at SMPN 9 Batam, the researcher get information by the teacher to take the data in class 8.4 and 8.7 because the ability at both of the class very less.

Table 2. Sample of the Students

\begin{tabular}{llll}
\hline No. & Sample & Class & Student \\
\hline 1 & Experiment Class & VIII. 4 & 30 Students \\
\hline 2 & Control Class & VIII. 7 & 30 Students \\
\hline \multirow{2}{*}{ Total } & & $\mathbf{6 0}$ Students \\
\hline
\end{tabular}

\section{Technique of Collecting Data}

The writer was collected the research data by giving instrumentation and validity test. Instrumentation consists of two tests, that are pretest that will be collecting before applying the strategy and the post-test is giving after applying the strategy. The second is test validity to see whether the test is valid or not.

\section{Instrument}

The instrumentation in this research was reading test. The aim of the test is to know the students' ability in reading comprehension after giving the treatment. In this test the writer prepared the test in the form of multiple-choice questions. The researcher focused on genre of descriptive text.

\section{Reading Comprehension Test}

Reading comprehension test was given to make evaluation. It included of various items which were answered by the students and then the result of the test was about how effective the think-talk-write strategy to students' reading comprehension. The test was taken by using written test. The test namely:

\section{Pre-test}

The researcher was given the pre-test to the students. The pre-test is in multiple choice tests. The test consists of 40 questions. 


\section{Post-test}

The writer was given the post-test to the students. The test would be similar with the pre-test. However, the post-test is given after the treatment had been done by teaching reading comprehension by used Monitor Comprehension Strategy.

\section{Testing Instrument}

\section{Test of Validity}

According to Arikunto (2006:168) states validity is a measure that indicates the levels of validity of an instrument. The result of validity items $r_{\text {calculated }}$ gathered, each items consulted to $r_{\text {table }}$ with $n=35, r_{\text {table }}=0.334$. item which has $r_{\text {calculated }}>r_{\text {table }}$ called valid item.

\section{Reliability Test}

The writer used Kuder Ricahrdson formula or called KR-20 formula to measure the reliability of instrument. The reliability data collected from the valid questions there were 22 valid questions. The writer counted the total variance of the test before find the reliability with KR-20 formula.

\section{RESULTS}

\section{Normality Test}

Normality testing was analyzed toward two of the data groups, they were reading comprehension narrative text data of pre-test and reading comprehension narrative text data post-test. The writer used Chi Squared formula by Riduwan (2011: 187). The criteria of normality test is if the $\mathrm{X}^{2}$ observed $<\mathrm{X}^{2}$ table, so the instrument is in normal distribution.

\section{Homogeneity Test}

The homogeneity test used to know whether each group had the same variance or not. It was tested by using $\mathrm{F}$ test.

Table 3. Summary of homogeneity test

\begin{tabular}{lllll}
\hline No & Variable & $\mathbf{F}_{\text {observed }}$ & $\mathbf{F}_{\text {table }}$ & Conclusion \\
\hline 1 & Pre-Test & 1.792 & 1,772 & Homogeneous \\
\hline 2 & Post-test & 1.100 & 1,772 & Homogeneous \\
\hline
\end{tabular}


Based on the table of homogeneity testing summary above, it could be concluded that $F_{\text {observed }}$ for student pre-test reading comprehension (1.729) and post-test reading comprehension (1.100) was lower than the ratio of $F_{\text {table }}(1.77)$. It means that both of the variances were homogeneous.

\section{Testing Hypothesis}

In order to see the effect of Monitor Comprehension Strategy to students' reading comprehension, the data was analyzed by using T-test formula. Before the data calculate by using t-test formula, the writer have to found out the correlation between post-test in reading comprehension and Direct Reading Thinking Activity by using correlation product moment formula:

\section{T-test}

After the writer found the correlation of the two variables the writer would to find the t-test to know the effect of the strategy towards students' reading comprehension by using t-test formula. The process of t-test can be seen as follow:

$$
\begin{aligned}
\mathrm{t} & =\frac{\bar{x}_{1}-\bar{x}_{2}}{\sqrt{\frac{s_{1}^{2}}{n_{1}}+\frac{s_{2}^{2}}{n_{2}}-2 r\left(\frac{s_{1}}{\sqrt{n_{1}}}\right)\left(\frac{s_{2}}{\sqrt{n_{2}}}\right)}} \\
& =\frac{70.785-67.145}{\sqrt{\frac{48.730}{35}+\frac{59.025}{35}-2.0,98\left(\frac{6.92}{\sqrt{35}}\right)\left(\frac{7.68}{\sqrt{35}}\right)}} \\
& =\frac{3.64}{\sqrt{1.39+1.68-1.96\left(\frac{6.92}{5.9}\right)\left(\frac{768}{5.9}\right)}} \\
& =\frac{3.64}{\sqrt{3.07-1.96(1.17)(1.3)}} \\
& =\frac{3.64}{\sqrt{3.07-2.98}} \\
& =\frac{3.64}{\sqrt{0.09}}=\frac{3.64}{0.3}=12.13 \rightarrow \text { T-count }
\end{aligned}
$$




$$
\begin{aligned}
\text { Level of freedom }(\mathrm{db}) & =\mathrm{n}_{1}+\mathrm{n}_{2}-2 \\
& =35+35-2 \\
& =70-2 \\
& =68(\alpha=0,05), \mathrm{t}_{\text {table }}(1.671)
\end{aligned}
$$

Based on the regression for hypothesis with 5\% (=0.05) of significant level and the value of t-table of the level of freedom 35. The value t-obtained (12.13) was bigger than the value of t-table (1.671). It means that the alternative hypothesis was rejected. It can be concluded that Monitor Comprehension Strategy had significant effect on the reading comprehension.

\section{DISCUSSION}

Based on the analysis of instrument testing and hypothesis testing as above, the researcher could make an interpretation that teaching reading comprehension by using Monitor Comprehension Strategy is more effective than teaching by using DRTA. From the Monitor Comprehension Strategy, student's has shown their attention to the material.

In addition, Monitor Comprehension Strategy makes the students learn and enjoy the class because they will discuss they are ideas and can sharing with their group and also can find the conclusion in the end of the discussion. The mean score of reading comprehension of experimental class respectively were 70.50.In contrast, the mean score of reading comprehension of control class respectively 66.97. Based on discussion above, the Monitor Comprehension Strategy better result on student's reading comprehension.

Based on the result of the discussion derived from the data analysis presented in the previous chapter, it can be concluded that the students who were taught by using Monitor Comprehension Strategy (MCS) got better achievement than the students. The success of this research can be proved by the students' score in the pre-test and post-test.

1. Based on calculation of pre-test and post-test in experimental and control class. The mean score of experimental group for pre-test was 64.86, while the mean score for post-test was 76.71. Then the mean score of control group for pre-test was 62.43, while the mean score for post-test was 71.86. It was shown that the students who got treatments with Monitor Comprehension Strategy (MCS). 
2. Based on the regression for hypothesis with $5 \%(=0.05)$ of significance level and the value of t-table of the level of freedom 35. The value t-obtained (12.13) was bigger than the value of t-table (1.671), the alternative hypothesis was accepted and the null hypothesis was rejected. It can be concluded that Monitor Comprehension Strategy can be effective on reading comprehension.

Dealing with the research finding, the following suggestion as the outcomes of the study is put forward. Those are expected to be useful for coming researcher, the teacher of English, and for whom that may be concerned with English education and particularly, teaching reading comprehension.

Therefore, the researcher has some suggestion. The first, the English teacher should determine the use Monitor Comprehension Strategy as an alternative strategy in reading comprehension. Then, for the other researcher, it is suggested to carry out further studies about the use of Monitor Comprehension Strategy and the other technique in developing students' reading comprehension since this study only concern about the use of Monitor Comprehension Strategy in developing students’ reading comprehension.

\section{REFERENCES}

Arikunto, S. (2006). Prosedur penelitian suatu pendekatan praktik. Jakarta: PT Asdi Mahasatya.

Riduwan. (2011). Dasar-dasar statistika. Alfabeta. Bandung

Sugiyono. (2009). Statistika untuk penelitian. Bandung: Alfabeta 